\title{
The Killing Fields of the American Southwest: Notes from the Arizona Borderlands, Part 3
}

\author{
Linda Green ${ }^{1}$
}

Published online: 10 January 2022

(c) The Author(s), under exclusive licence to Springer Nature B.V. 2021

\section{Killing fields - a place where heavy loss of life has occurred (often as a result of} massacres, genocide, war and conflict

I have lived in the southwest borderlands for over twenty years, a period that parallels the dramatic rise in migrant deaths along its boundary Now tallied at over $8,000+{ }^{1}$ Weather conditions are often extreme: each year the punishing summer heat - this past June a week of record breaking temperatures in Tucson $(115 \mathrm{~F})$ and Phoenix (118 F) - combined with monsoon rains that turn desert washes (dry river beds) into torrents, while winter night temperatures may well linger below freezing.

One hundred eighty-eight recovered bodies or skeletal remains were found in the Tucson sector in fiscal year 2021. ${ }^{2}$

Less than half have been identified. They are the de facto disappeared. ${ }^{3}$

Yet, these migrant deaths are not simply due to bad luck, being misinformed, or random acts of nature. The loss of so many lives while crossing the Sonoran Desert, 800,000 square miles straddling the US-Mexico divide, over the past two decades must be framed within a set of ongoing US Federal policies and practices. By the mid 1990s then President Bill Clinton adopted the "prevention through deterrence" strategy, premised on a combination of US Department of Defense Center for Low Intensity Conflict policy document and the Border Patrol Strategic Plan of 1994. Both reports advocated for forcing migrants to travel across the more dangerous regions of the borderlands. In particular, the strategy ${ }^{4}$ was designed to push people away from more established routes located near ports of entry and into the harsh terrain of the Sonoran Desert in Arizona. Government officials claimed publicly that

\footnotetext{
1 Some analysts believe the numbers could be much higher, as many as three times higher.

2 Customs and Border Patrol-2021.

3 The "disappeared" people adducted by force from either state or non-state actors. For any families there is never any resolution of what happened to the person "disappeared.".

4 Operation Streamline, Safeguard and Hold the Line See Nevins, Joseph, Operation Gatekeeper and Beyond.: The War on "Illegals" and the remaking of the US-Mexico Boundary 2010 London: Routledge.
}

Linda Green

lbgreen@arizona.edu

1 School of Anthropology, University of Arizona, Tucson, USA 


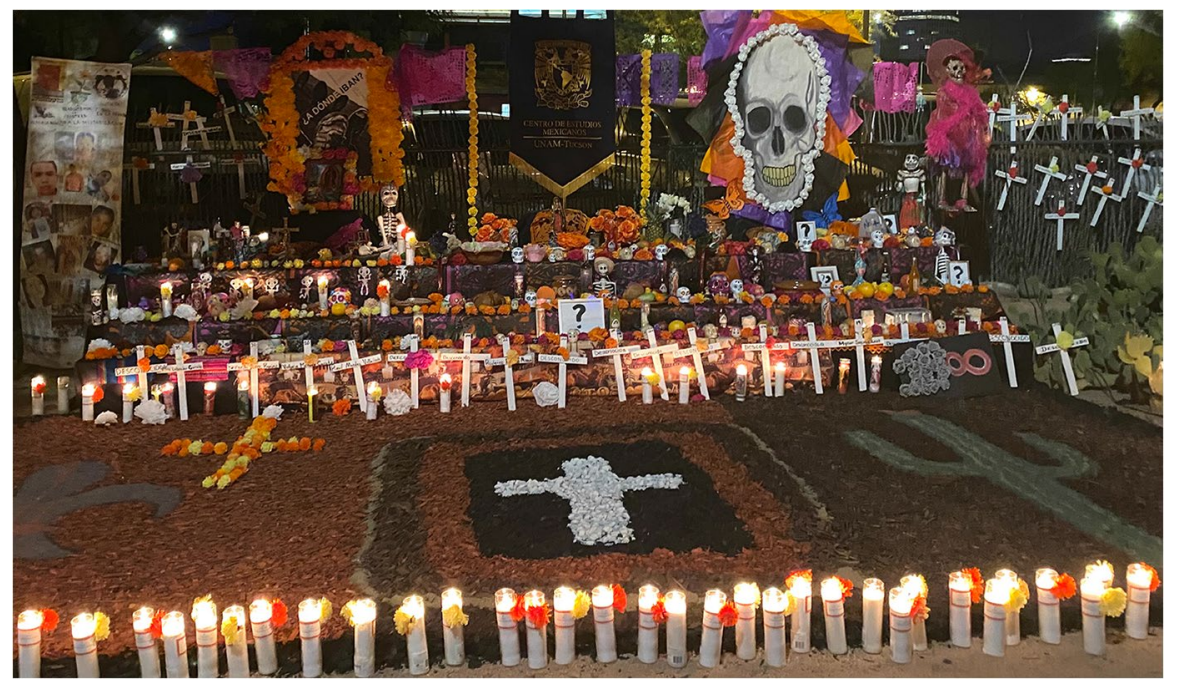

El Dia de los Muertos, Tucson November 2021 El Tiradito Wishing Shrine Altar and candles to honor each of the 188. Their names, including those unidentified, were read aloud

migrants would make a cost-benefit analysis and choose not to cross, even as they noted in private exchanges that such calculations would not be an option for many. Rather decisions would be undergird by the imperatives of life or death. Now these dead bodies and skeletal remains are potent, albeit silent, testimony to US policies of exclusion. ${ }^{5}$ And while this social amnesia hangs heavily over the entire region, the continuation of such policies for more than two decades points to their salience as US immigration practices.

As the map below indicates, the territorial boundaries of the Tohono O'odham Nation of southwest Arizona demarcate one such killing field along the US-Mexico border. Many of the migrants whose remains have been found are indigenous peoples from southern Mexico and Central America. While acknowledged on the ground, it is a fact infrequently indexed in the public domain. Yet, this desert landscape - these sacred lands of the O'odham peoples - embodies not only the recently split blood of migrants cum refugees but two centuries of settler colonialism with its attendant violence, dislocation, and ethnocide directed against autochthonous peoples. Over the course of the twentieth century even as processes of dispossession and dislocation reworked the lives and livelihoods of the indigenous peoples living in the southwestern region, many continued to cross the border rather freely for trade, work and for kin ties. Now the sovereign O'odham Nation has been militarized and become a key site of the killing fields along the borderlands.

\footnotetext{
5 This exclusion is premised on a significant number of migrants making it into the US as they serve as much needed cheap labor force.
} 


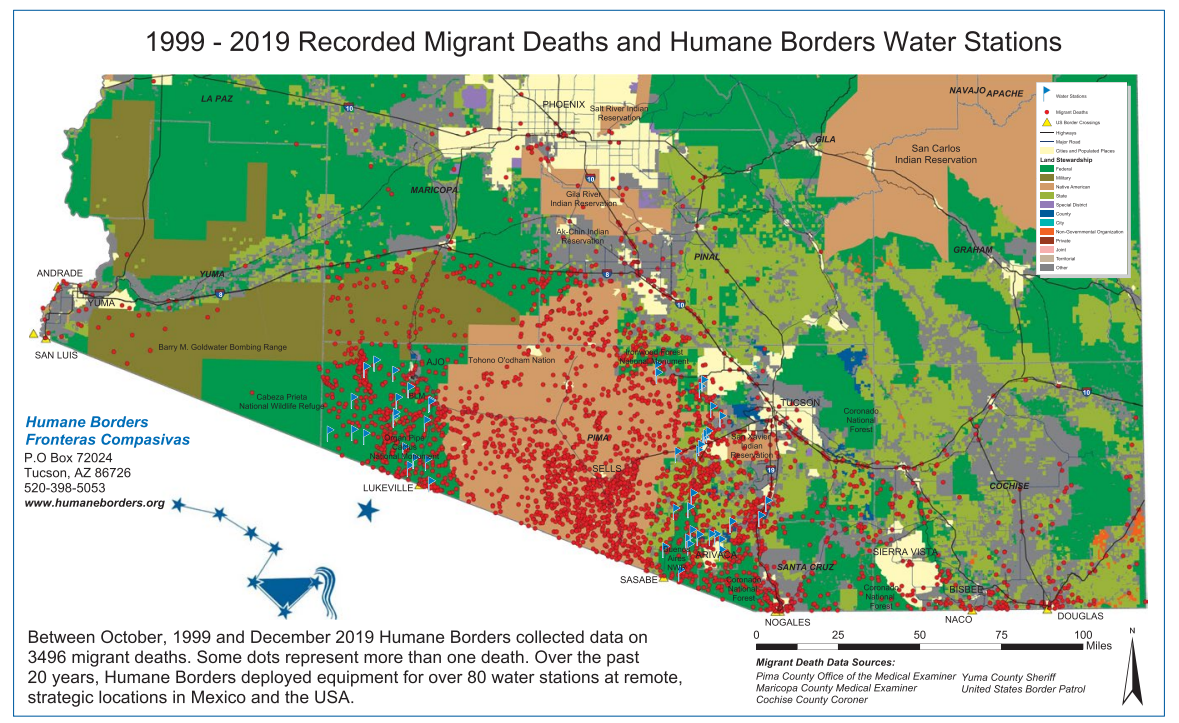

Humane Borders Map

The historical origins of the killing fields at the boundary between the US and Mexico can be traced to the Treaty of Guadalupe of 1848 which ostensibly ended the Mexican-American War and to the Gadsden Purchase of 1853 - where for $\$ 15 \mathrm{~m}$ the US acquired 1/3 of Mexican territory at the time: the region that comprises the US states of New Mexico, Utah, Nevada, Arizona, California, Texas, and western Colorado. It was not until some 50 years later, in 1924 with official formation of a Border Patrol, that one of the primary foci of the agency was to prevent smuggling, particularly alcohol, across the border during the US Prohibition period (1919-1933). With the end of Prohibition, the Border Patrol's attention turned more fully to control of migrant labor, mostly from Mexico. ${ }^{6}$

Today sophisticated smuggling operations are in fact multibillion dollar enterprises. The Mexican cartels and their surrogates traffic in migrants and the lucrative, illicit drug trade. ${ }^{7}$ After 9/11 with the creation of the US Department of Homeland Security the fight against "terrorism" nee militarization was added to the mix.

By century's end three fundamental changes reconfigured the formation, policies, and practices of the southwest borderlands strategy:

+ The North American Free Trade Agreement (NAFTA) 1994 and followed by the Central American Free Trade Agreement (CAFTA) 2005 have created the

\footnotetext{
${ }^{6}$ Some scholars argue that using the environment as a physical deterrent migrants crossing from Mexico to the US began with Chinese Exclusion Act 1882. As a result Chinese workers were barred from entering the US; thus, they began to cross unauthorized into the US along the southern border. See De Leon, Jason The Land of Open Graves Berkeley: UC Press 2015.

${ }^{7}$ Lucrative drugs include black tar heroin, cocaine, fentanyl, and methamphetamine. By the US CBP's own admission, $80 \%$ of these high valued drugs pass through ports of entry undetected.
} 
conditions for the United States to become a magnet for cheap, exploitable, and "illegal" migrant labor. The fallout from NAFTA in Mexico was swift. In the first year after the passage of NAFTA over 1 million peasant farmers lost their land. Although such agreements were touted as the key to prosperity in Mexico and Central America in fact the number of migrants crossing the border rose after its implementation.

+ Prevention through Deterrence - three decades later as the "securitization" of the border has continued apace, so too has the price to cross with a coyote (guide) soared and the routes themselves ever more remote and treacherous. Deaths, disappearances, permanent injuries, detentions, and deportations/expulsions are the norm.

+ The increased militarization of the US-Mexico borderlands has turned the region into a war zone, resulting in a precipitous rise in violence, injuries, and death. Moreover, at times border agents look more like troops ready for battle with their assault rifles and tactical gear than law enforcement encountering unarmed civilians seeking safety. The border wall, now 766 miles long, covers about $40 \%$ of the total length of the border. It has been a boondoggle from its inception. Yet under Trump it quite literally reached new heights. In many areas the 30-feet-high bollard style wall now divides communities on both sides of the border, threatens wildlife, and damages environmental resources. Military technologies of surveillance have proliferated; Blackhawk helicopters, drones, and high-tech sensors abound.

Yet, according to a study by Doctors Without Borders (2020), ${ }^{8} 2 / 3$ of the people from the Northern Triangle countries seeking refuge have experienced a murder, disappearance, or kidnapping of a relative before their departure.

Now, a 2500 mile corridor of crimes and corruption extends from the US-Mexico border, southward to encompass both the Mexico-Guatemala boundary and the Guatemala-Honduras divide. Much of this militarized operation is financed, equipped, and trained by US military and law enforcement officials. ${ }^{9}$ The border too also extends 100 miles into the interior of the US from aony border, land or water. Thus, 200 million Americans live within what the ACLU has called "Constitution Free Zones" where anyone can be stopped by ICE without probable cause.

Inside this bounded off region from Central America to the US-Mexico border - drugs, guns, and humans are bought and sold, cartels flourish, while the people passing through the region alongside those who live there, are extorted, surveilled, abused, and murdered with impunity.

\footnotetext{
${ }^{8}$ Doctors Without Borders 2019 No Way Out The Humanitarian Crisis for Migrants and Asylum Seekers Trapped between the United States, Mexico and the Northern Triangle of Central America.

9 See Miller, Todd Empire of Borders: The Expansion of US Borders Around the World 2019 London: Verso.
} 


\section{By the numbers}

Deaths In fiscal year 2021557 deaths across the 2000 miles of border (found bodies by BP, or involved in an emergency response); the most ever reported in the 22 years in which BP has kept records (1998).

Disappearances No one knows for sure. Mexico estimates that in the last 15 years 100,000 people have disappeared within its borders. Add in another estimated 30,000 Central Americans over a ten-year period and the numbers become staggering.

Detentions 20211.66 million migrants detained for unlawful crossing — record number of apprehensions. Sixty-one percent expelled under Title 42 (see below).

These numbers both index the enormity of the situation and desperation of many. But also many of these apprehensions represent what in Border Patrol parlance is referred to as "recidivist crossings"; a person crossing more than once. A much more common affair now than pre-COVID.

Deportations have ceased since the invocation of the public health measure Title 42 (see below). Migrants and refugees are being expelled to wait in Mexico. Reportedly there are at least 20,000 people waiting in Mexico along the border hoping to have their asylum claims processed. For example, the US State Department classifies the Mexican border state of Tamalipus at the same level of danger as Syria, Iraq, and Afghanistan.

\section{Corruption, abuse, and murder}

$16,000+$ Border Patrol agents are stationed along the southern border. Laxity in recruitment standards under George $\mathrm{W}$ Bush have led to increased corruption and criminal activity within Border Patrol ranks, including money laundering, smuggling, and conspiracy. In fact, the FBI has called corruption within Customs and Border Protection ( $\mathrm{CBP}$ ) ranks as one of the serious sources of criminal activity along the border. By CBP's own admission, $80 \%$ of profitable drugs smuggled into the US along the southern border are through ports of entry.

+ In a 2021 report, Human Right Watch alleged that US Broder Patrol agents engaged in physical and sexual abuses against asylum seekers. After six years of legal battles, DHS has acknowledged 160 cases of misconduct and abuse including child sexual assault, enforced hunger, threats of rape, brutal detention conditions, and denial of the right to due process with regard to their asylum claims.

Dereliction of duty According to a 2021report, Left to Die, by the Tucson-based humanitarian groups Coalition de Derechos Humanos and No More Deaths, the Border Patrol did not conduct a research and recuse operation in $64 \%$ of the reported cases even though they are the agency solely responsible for such undertakings. 


\section{Murder}

Since 2010150 people have died at the hands of Border Patrol. Seven were standing in Mexico. Six were children. In the almost100 years since the formation of Border Patrol, no agent has been convicted of murder while on duty.

What is of concern to me is that these very same issues have been ongoing for decades and yet nothing changes in terms of halting these atrocities. Occasionally something egregious surfaces; outrage and shock follow with promises of a full inquiry to hold those responsible.

Nothing happens. Nothing changes. We know nothing.

Silence prevails.

Crimes against humanity - are not isolated or sporadic events but are part of a government policy or a wide practice of atrocities tolerated or condoned that can be committed during peace or war. Crimes against humanity have three key components: a physical element - that includes inhumane acts; a contextual element: "when committed as part of a widespread or systemic attack directed against any civilian population"; and a mental element: "with knowledge of the attack." According to Article 7(2) of the Rome Statue, the plan or policy does not need to be explicitly stipulated or formally adopted and can therefore be inferred from the totality of the circumstances.

Some legal scholars have proposed an "anti-impunity" strategy to hold those accountable for human rights abuses at borders by turning to international criminal law as a mechanism for protection of migrants and refugee rights. ${ }^{10}$ Effective as it has been as a discursive strategy, its value to date in criminal prosecutions and convictions against those making policy and those enacting it has been only partial. But what it has importantly done is shifted the focus of culpability from solely nation states to individuals, including corporations, state institutions, like Border Patrol/ DHS and perhaps even cartels. Additionally, it demands explanations from the perpetrators, in this instance ICE and Border Patrol, for the ongoing, yet unnecessary, violence and abusive treatment ${ }^{11}$ of migrants and refugees.

The last living prosecutor at the Nuremberg Trails declared that Trump had committed crimes against humanity with the separation of children from the family members at the border and placing them in cages. Others have called "deterrence" crimes against humanity because it sanctions violence toward some migrants in order to "deter" other would be migrants (see Mann).

Perhaps might we also think of these crimes as cumulative and chronic rather than singular events. Taken together they are constitutive of the three crucial elements of crimes against humanity: the physical, contextual, and mental. In a similar vein Catherine MacKinnon, a special advisor on gener to prosecutors at the

\footnotetext{
${ }^{10}$ Mann, Itamar "The New Impunity: Border Violence as Crime”, (nd) UPenn Journal of International Law 42.

11 The infamous hieleras (iceboxes) freezing cold detention cells at BP sites where people may be kept for days without any relief.
} 
The banner with faces of those killed by BP

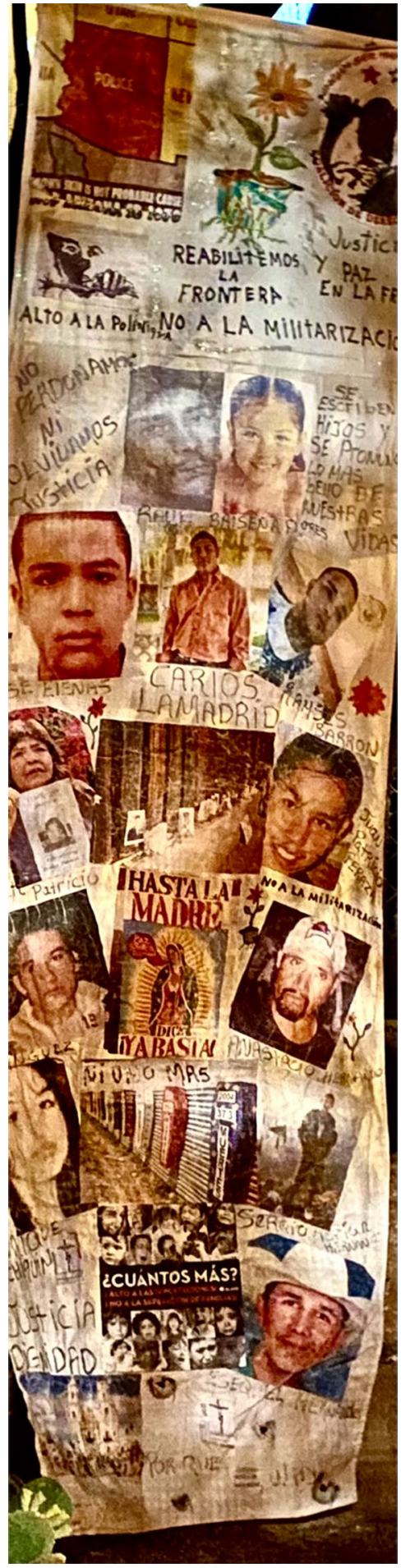

Springer 
International Criminal Court, opined that violence against women around the world is the "longest running siege of crimes against humanity in the real sense. ${ }^{12}$

+ Clinton created the logistical conditions for the killing fields - through prevention through deterrence and Operation Gatekeeper. He signed into law NAFTA.

+ Bush - post 911 - expanded the number of BP agents while lowering the standards for hiring of agents. Some agents BP reportedly have an allegiance or affiliation with cartels. Bush recruited among troops returning from Iraq and Afghanistan, but then never instituted training measures to transition from a "shoot to kill" mentality of the military to the largest civilian law enforcement agency in the US.

In 2004 Bush created the Department of Homeland Security and Custom and Border Protection whose stated primary role is the prevention of terrorism. He signied and funded of the Merida Initiative (see below).

+ Obama said he was only deporting those with criminal records: 2.5 million people - but many with criminal records were as a result of being processed through Operation Streamline. ${ }^{13}$ The Obama administration repeatedly violated the non-refoulment clause of international law. The principle of non-refoulment in international law forbids a nation-state to forcibly return asylum seekers and refugees to a country where they are liable to be subjected to persecution. Yet, under the Obama administration, thousands of mostly women and children were sent back to the Northern Triangle countries from which they fled in fear of their lives. Most never even had a credible fear interview which establishes the validity of the asylum claim. The US skirts the Principle by insisting that the governments of the Northern Triangle countries are not the perpetrators of the crimes. Hence, the US government is acting within the law.

+ Trump in 2018 instituted Migrant Protection Protocols, now infamously known as "Wait in Mexico" and in March 2020 invoked Title 42, an obscure public health law. In both instances the Trump administration was able to effectively shut down asylum and refugee claims. Under MPP an asylum seeker at the border is given a notice to appear before an asylum officer and then they are sent to Mexico to wait. The date, time, and port of entry where they should enter for their hearing can vary considerably. For example, those who sought permission at the port of entry in Nogales, AZ, were directed to appear at the port of entry in El Paso, TX, some three hundred miles away. ${ }^{14}$ If people were able to wait in Mexico, then the adults were held in detention and separated from their children.

\footnotetext{
12 As quoted in Mann, Catherine MacKinnon, Special Gender Advisor to the International Criminal Court (ICC) prosecutor. The International Criminal Court and Gender Crimes, Address at Consultative Conference on Internal Criminal Justice (September 11, 2009).

13 See Green, Linda 2008 “A Wink and A Nod: Notes form the Arizona Borderlands" Dialectical Anthropology.

14 The Biden Administration initially tried to shut down the program when it took office, but the US courts have consistently reinstated the program.
} 
During the past year the executive branch of US government changed hands. We witnessed - or some thought at the time - the last of the Trump era of brutality at the border: vicious, ruthless, unnecessary.

Biden was heralded to be the change we could believe in, but the difference is in degree not in kind. The cruelty of Biden Administration is simply feckless and heartless: Kamala Harris" "do not come" is but a more starkly rendered example. Moreover, Biden acted astonished after seeing the images of Border Patrol agents on horseback whipping Black Haitian refugees, by an agency of which he is in charge. "It's outrageous. I promise you, those people will pay," President Biden said.

This incident occurred in September 2021, as I write this in November nothing publicly has been revealed about the course of the investigation. More than likely it will yield little, if previous cases of Border Patrol crimes are a measure. Border Patrol agents have been implicated on numerous occasions; sometimes they are indicted, but almost never are they punished for their crimes.

Impunity in its legal sense reigns.

Perhaps the most egregious, however, is the Biden administration's refusal to withdraw Title 42 because he claims inexplicably that it is still a necessary public health measure, even in the face of stern rebuke from public health officials. Title 42 does not allow anyone coming to the US borders - Mexico and Canada — to enter the US and are immediately expelled to either Canada or Mexico. The law does not apply to US citizens who are able to cross unimpeded, which in itself undermines the scientific veracity of its claims. And if we are really concerned with good public health practices especially during the COVID-19 pandemic, then why not take the next logical epidemiological step: vaccinate - and if necessary treat those who are sick - and vaccinate before they are expelled. An amendment to the law now allows unaccompanied minors to enter the US.

Otherwise, asylum seekers with children are forced to wait in the streets of border cities in Mexico: most often without adequate shelter, food, and medical care. Gangbased violence including femicide is notorious.

\section{Why do they come}

Month by month they leave their homelands. They leave because there is nothing there except their everything, which does not offer enough to feed their children. Once it did. This is the poverty of the new capitalism. John Berger, Hold Everything Dear (2007:24).

Extraction, trafficking, climate chaos - the multiple expressions of political economic and social dispossession and dislocation circumscribe the lives of the majority in the region. Those who flee are the children and grandchildren of counterinsurgency that marked the Northern Triangle countries in the 1970s, 80s, 90s. Now these young people live its legacies on a daily basis: lawlessness, poverty, gang violence, extortion, murder, femicide. ${ }^{15}$ Yet there has been a silence about the past not

\footnotetext{
15 The Northern Triangle countries continue with some of the highest homicide rates in the world in countries not at war. Likewise, femicide.
} 
only at governmental level in the Northern Triangle countries but within families and communities about who did what to whom and the blood on people's hands.

Now youth leave their everything — their ancestral lands, their kin, the landscape of their lives. As has happened over centuries that landscape is once again soaked in blood.

In his book, This Land is Our Land: An Immigrants Manifesto, Sukelu Mehta recounts an incident between his grandfather and a British man in the 1980s. Mehta's grandfather was born in India but he spent much of his adult life working in colonial Kenya. In London in the 1980s, they have the following exchange which perhaps best captures the essence of "why they come":

"Why are you here" the British man demanded, "Why are you in my country?"

Mehta writes that his grandfather in essence replied:

"We are here, because you were there."16

Historically and in the contemporary period bloody, militarized US footprints are evident across the region.

+ The 1954 CIA-sponsored coup in Guatemala set the institutional and militarized framework for what would become genocide against the Mayan people. Trained, funded, armed, and advised Guatemalan military in counterinsurgency since the 1960s even as they knew of the crimes being committed against the people of Guatemala. For the next sixty years, the US has funded, trained, and equipped the Guatemalan military even as they committed genocide. Since that time the Guatemalan population has lived its legacies: violence, corruption, gross inequalities, ongoing human rights violations.

+ El Salvador — in December 1981 the El Mozote massacre stands out as one of the largest massacres in Latin American history. The Salvadoran elite counterinsurgency unit, Atlacatl Battalion, was formed and trained by the US. The battalion occupied El Mozote over three-day period while they systematically killed an estimated 1,000 civilians, mostly women and children, including 248 children under the age of six. ${ }^{17}$

+ Honduras — in the 1980s, Honduran territory served as a staging ground for the CIA-backed Contra War with Nicaragua. More recently, the US was involved in the coup d'état of then elected president Manuel Zaleya in 2007. Violence and corruption are endemic. The current President Juan Orlando Hernandez was implicated in the recent trial of his brother, Juan Antonio Hernandez, who was convicted (March 2021) in the US Southern District of New York. He was charged with transporting 185,000 kilos of cocaine into the US. Honduras receives billions of dollars in foreign aid and Honduras, like EL Salvador and

\footnotetext{
16 As quoted in Todd Miller's new book, "Build Bridges Not Walls" 2021 Haymarket Books.

17 See Joh Lee Anderson's essay "Is El Salvador's President trying to shut down a hearing on the infamous El Mozote massacre" in the New Yorker September 2021.
} 
Guatemala, consistently has some of the highest rates of homicide and femicide in the world. In late November Hondurans elected Xiomara Castro, the first female president and wife of ousted president Manuel Zaleya.

+ Mexico - the 2007 Merida Initiative was signed by then President George W. Bush and Mexican President Felipe Calderon. Its stated objective was to impede drugs from flowing across Mexico and into the US. Mexico received \$3.3 billion in assistance for training, equipping, and funding the military. The Mexican military deployed thousands of heavily armed troops into the streets to do battle in this war on drugs. However, in the first years alone, the number of deaths, disappearances, and human rights violations soared: many attributable to military troops. Often the troops are deployed against protests by unarmed civilians.

The involvement of both the Mexican military and law enforcement in the disappearance of the 43 students from Ayotzinapa in Guerrero in 2014 is but one example of the entanglement of the Mexican military in crime and corruption.

\section{What do we owe each other}

When I ask my students ${ }^{18}$ they overwhelmingly respond:

justice — being held to account.

dignity - a presence in the world that asserts boundaries of humanness, of fortitude, compassion and hope that emanate from our vital connections with each other. Thus facilitating the ability to do the right thing even in the face of adversity. A sense that you count for something.

Yet, historical amnesia prevails in the US public arena, thus rendering invisible our complicity in these atrocities across Mexico and the Northern Triangle in the past and in the present.

\section{Impunity reigns}

In this instance impunity can be thought of as something more than simply a lack of accountability in the legal sense, but also a social process that is enabled in part by a characteristic mixture of silence and shame among its victims and widespread indifference and historical amnesia on the part of the dominant society.

Indifference breeds impunity which breeds indifference in increasingly vicious cycles where the possibilities of making common cause with others seems to diminish with each round.

When I ask my students why indifference prevails here in the Tucson sector - a two hundred mile stretch that lies 60 miles south of Tucson — where those 188 human remains were found this past year.

They respond:

we don't hear anything about them

we pay no attention because we are not used to being around strangers.

\footnotetext{
18 These insights from my undergraduate students at the University of Arizona and my students who are incarcerated at an Arizona State Prison complex in Tucson.
} 
Once in a while, a catastrophic event will break through for a news cycle:

+ A highspeed rollover car crash killing tens of migrants in an overloaded van being pursued by Border Patrol.

+ A tractor trailer loaded with migrants hidden inside. Packed in with little ventilation, food, or water for hours or even days. More likely than not children are involved.

$+15,000$ Haitian refugees and migrants under the bridge in El Rio Texas and from where 9,000 of them were sent back to Haiti were merely a comment. Haiti with a murder rate that rivals Central America and where gangs control much of the capital.

Then back to our own lives with little concern for others.

\section{Stories from the Arizona-Sonoran border}

Perhaps it is through stories where spaces of possibilities and hope may emerge, offering a way forward to translate private misery into public concerns and considerations. ${ }^{19}$

In his 1975 book A Seventh Man, about migration, John Berger writes in the preface: "To outline the experience of the migrant worker and to relate this to what surrounds him - both physically and historically - is to grasp more surely the political reality of the world at this moment. ....its meaning is global. Its theme is unfreedom. ${ }^{20,}$

\section{Nogales, Sonora}

It's mid-June at 8am and the temperature reads 96F. The weather forecast predicts that it will reach $115 \mathrm{~F}$ today. I walk across the border at Nogales port of entry, not sure what to expect. Just on the other side of the border a rather flimsy plastic walled ramada has been erected outside of the office of Mexican immigration. Seated inside on plastic chairs that day were about 25 young men, all Guatemalans between the ages of 18 and 37 years old, who had been picked up by Border Patrol in the Sonoran desert on the US side. They were processed throughout the night and in the early morning they were expelled to Mexico under the provisions of Title 42. Once processed in Mexico they would be bussed to Hermosillo, Sonora, about a 175-mile drive from Nogales. From there they would be flown back to Guatemala City. This is not counted by the US as deportations, but rather expulsions.

No one had any water or food. One of my graduate students and I went to buy some basic provisions. When we returned the men had been moved to the pavement under a tree nearby. Now the ramada was occupied by young women and children; thirty five in all. They too were Guatemalans.

19 See Mills, C Wright 1959 The Sociological Imagination Oxford: Oxford University Press.

20 Berger, John The Seventh Man 1975 London: Verso Books. 
Over the course of the next five hours, we wait for the only Mexican official who can process them. The women hope to find shelter space for the night. If not they will be forced to sleep on the street, which will expose them to the dangers of extortion, kidnapping, and rape. Despite what they have been through, the women seem to have some degree of hope.

The men await their deportation.

All the men tell me that they saw at least one dead body while in the desert. One young man described a pile of bodies he inadvertently stumbled over. Another had been lost in the desert for six days. He sat among the group, dazed and fearful. As the hours passed, the men became more talkative. Why, they want to know, does the US not let them in to work? Why do the Cubans and Venezuelans get in without any problems? They come to work because they cannot survive in Guatemala. Violence is the name of the game; many have lost their land, gangs control their region, and extortion is the currency of survival. They understand that asking for asylum is futile for men. So they come as migrants cum refugees. They come because Guatemala is unlivable. They want a future. If they stay in Guatemala, they fear that they do not have one. Most say they will try again. The price of a coyote (guide) to get them across is high (US\$ 10,000) but with that they are afforded three tries. What do they have to lose, they say. Better to die while trying than to stay at home.

The women come to ask for asylum. Most have experienced brutal violence in their households and/or their communities. Young and vulnerable, 19-35 years old, most have little or no protection. Like most of the asylum cases in which I have testified as an expert witness, the savagery of the violence is painful to hear, unimaginable to experience. Like most they come from areas where there were massacres during the counterinsurgency war.

At last the official arrives around $2 \mathrm{pm}$. As we take leave of one another, I stand amidst the women, saying goodbye. Our eyes brim over with tears. Some of the kids notice that I am crying and several come to hug and comfort me. At that, my student tells me later, is when he too was moved to tears.

Tohono O'odham Nation.

September 2020 - two members of the Hia Ced O'odham, Amber Ortega and Nellie Jo David, were arrested for a non-violent protest blocking border wall construction that threatened a sacred water source, the Quitobaquito Springs, at the edge of the Organ Pipe Cactus National Monument. The spring has been an integral cultural and spiritual site of O'odham traditions. During construction of Trump's 30-ft-high wall, a 1/8 mile from the springs, contractors moved across the delicate habitat of Organ Pipe, with heavy duty vehicles and pumped hundreds of thousands of gallons of water from the aquifer that sustains the springs. Both women blocked a construction vehicle from moving forward that day. They were arrested and inexplicably taken initially to a private men's detention facility, Core Civic in Florence AZ, before being processed. One of the women, Ms. David, accepted the option of probation and a fine. Ms. Ortega pleaded not guilty on the basis that her protest was centered in her spiritual beliefs that were hampered by the construction of the wall. The spring has been intermittently closed to O'odham peoples during construction of the 40-mile section of the wall. She is awaiting the verdict of a bench trial that happened in Tucson in November 2021. The judge will decide the verdict by 15 
Fruitvale section of Oakland, CA, 2021

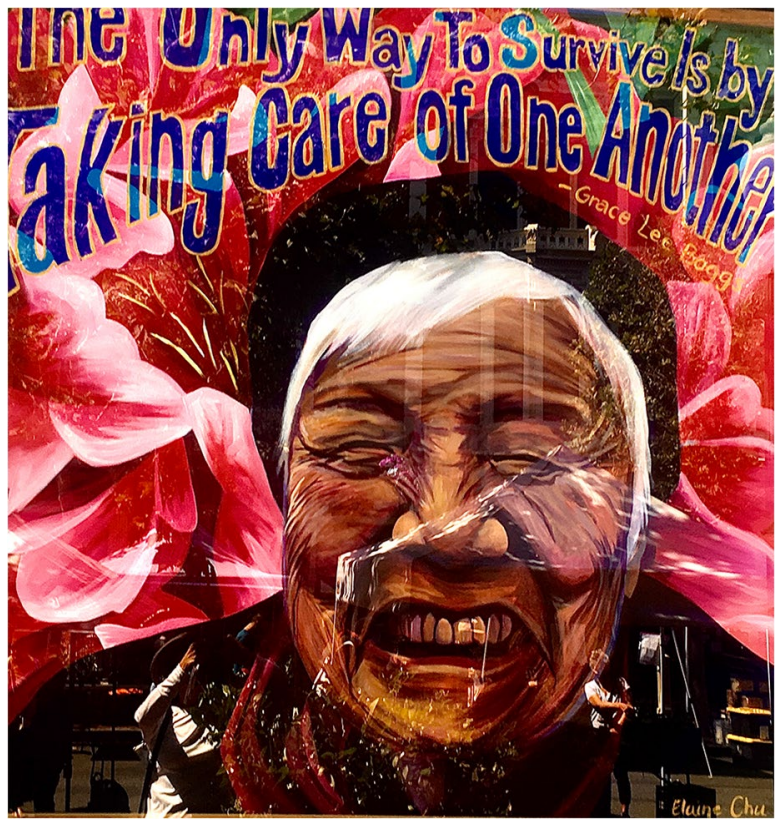

December but has already ruled that Ms. Ortega was not able to prove that the wall construction was a "substantial burden" on her religious activities.

What do we owe each other?

Justice and dignity

Guatemalan Mayan refugees and migrants alongside the Tohono O'odham land and water protectors.

respond with both their actions and their words.

they put their lives quite literally on la linea (the line).

for their rights as indigenous peoples to a dignified life and to freedom. ${ }^{21}$

Publisher's Note Springer Nature remains neutral with regard to jurisdictional claims in published maps and institutional affiliations.

\footnotetext{
21 see Nevins, Joseph The Right to the World Antipod 49(5):

November 2017 1349-1367.

See Byung Chul Han Psychopolitics, Neoliberalism and New Technologies of Power 2017 London: Verso According to Han originally freedom meant being among friends. Freedom and friendship have the same root. Freedom signifies a relationship.
} 